\title{
DO TRAINING REGIMEN AND COMPETITIVE LEVEL AFFECT BODY IMAGE DISSATISFACTION (LEANNESS AND MUSCLE TONE) IN FEMALE ATHLETES?
}

\author{
O REGIME DE TREINO E O NIVEL COMPETITIVO AFETAM A INSATISFAÇÃO CORPORAL (MAGREZAE \\ MUSCULARIDADE) EM ATLETASDO SEXO FEMININO?
}

\author{
¿EL RÉGIMEN DE ENTRENAMIENTO Y EL NIVEL COMPETITIVO AFECTAN LA INSATISFACION CORPORAL \\ (DELGADEZ Y MUSCULARIDAD) EN ATLETAS DEL SEXO FEMENINO?
}

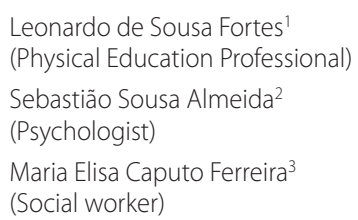

1. Universidade Federal da Paraíba, Department of Physical Education, João Pessoa, PB, Brazil.

2. Universidade de São Paulo, Faculdade de Filosofia, Ciências de Letras, Department of Psychology, Ribeirão Preto, SP, Brazil.

3. Universidade Federal de Juiz de Fora, Department of Fundamentals of Physical Education, Juiz de Fora, $M G$, Brazil.

\section{Correspondence:}

Leonardo de Sousa Fortes. Avenida Marechal Hermes da Fonseca, 584, apto. 201, Bessa, João Pessoa, PB, Brazil. 58035-190. leodesousafortes@hotmail.com

\begin{abstract}
Introduction: Studies that seek analyze the relationship between sport variables and body image are importants, because indicate if the competitive sport environment influence on body feelings of athlete. Objective: To analyze the relationship between sports variables (training regimen and competitive level) and dissatisfaction in regard to leanness and muscle tone in female athletes. Methods: One hundred and eighty female athletes aged over 12 years from various sport disciplines participated in the study. We used the Body Shape Questionnaire (BSQ) to assess dissatisfaction in regard to leanness. The dissatisfaction subscale of Drive for Muscularity Scale (DMS) was used to evaluate dissatisfaction with muscle tone. Training regimen (frequency $x$ daily hours of training) and competitive level were acquired through a questionnaire developed by the actual investigators. Results: The findings indicated a statistically significant relationship between the training regimen $\left(F_{(1,179)}=4.01 ; p=0.047\right)$ and competitive level $\left(F_{(2,178)}=3.59 ; p=0.031\right)$ and the BSQ scores. Moreover, the results indicated a statistically significant relationship between the training regimen $\left(F_{(1,179)}=4.01 ; p=0.047\right)$ and the competitive level $\left(F_{(2,178)}=3.59 ; p=0.031\right)$, with DMS dissatisfaction subscale scores. Conclusion: Sports variables (training regimen and competitive level) were related to dissatisfaction in regard to leanness and muscle tone, although they demonstrated different magnitudes. Level of evidence III; study case-control.
\end{abstract}

Keywords: Sports; Body dissatisfaction, Athletes.

\section{RESUMO}

Introdução: Estudos que busquem analisar a relação entre variáveis esportivas e imagem corporal são importantes, pois indicam se o âmbito esportivo competitivo influencia nos sentimentos direcionados ao corpo do atleta. Objetivo: Analisar a relação de variáveis esportivas (regime de treinamento e nivel competitivo) com a insatisfação direcionada à magreza e à muscularidade em atletas do sexo feminino. Métodos: Participaram 180 atletas com idade superior a 12 anos, pertencentes à diversas modalidades esportivas. Utilizou-se o Body Shape Questionnaire (BSQ) para avaliar a insatisfação direcionada à magreza. A subescala de insatisfação da Drive for Muscularity Scale (DMS) foi utilizada para avaliar a insatisfação com a muscularidade. O regime de treinamento (frequência $\times$ horas diárias de treino) e o nível competitivo foram coletados por intermédio de questionário criado pelos próprios pesquisadores. Resultados: Os achados indicaram relação estatisticamente significativa do regime de treinamento $\left(F_{(1,179)}=4,01 ; p=0,047\right)$ e do nível competitivo $\left(F_{(2,178)}=3,59 ; p=0,031\right)$ com os escores do BSQ. Ademais, os resultados apontaram relação estatisticamente significativa do regime de treinamento $\left(F_{(1,179)}=4,01 ; p=0,047\right)$ e do nível competitivo $\left(F_{(2,178)}=3,59 ; p=0,031\right)$ com os escores da subescala de insatisfação da DMS. Conclusão: As variáveis esportivas (regime de treinamento e nivel competitivo) estiveram relacionadas com a insatisfação direcionada à magreza e à insatisfação com a muscularidade, embora tenham demonstrado magnitudes diferentes. Nível de evidência III; Estudo Caso-Controle.

Descritores: Esportes; Insatisfação corporal; Atletas.

\section{RESUMEN}

Introducción: Los estudios que tratan de analizar la relación entre las variables deportivas y la imagen corporal son importantes, ya que indica si la avenida deportiva competitiva influye en los sentimientos dirigidos hacia el cuerpo del atleta.. Objetivo: Analizar la relación de variables deportivas (régimen de entrenamiento y nivel competitivo) con la insatisfacción direccionada a la delgadezy a la muscularidad en atletas del sexo femenino. Métodos: Participaron 180 atletas con edad superior a 12 años, pertenecientes a diversas modalidades deportivas. Se usó el Body Shape Questionnaire (BSQ) para evaluar la insatisfacción direccionada a la delgadez. Fue usada la subescala de insatisfacción de la Drive for Muscularity Scale (DMS) para evaluar la insatisfacción con la muscularidad. El régimen de entrenamiento (frecuencia x horas diarias de entrenamiento) y el nivel competitivo se recolectaron a través de un cuestionario creado por los propios investigadores. Resultados: Los hallazgos indicaron relación estadísticamente significativa del régimen 
de entrenamiento $\left(F_{(1,179)}=4,01 ; p=0,047\right)$ y del nivel competitivo $\left(F_{(2,178)}=3,59 ; p=0,031\right)$ con los puntajes de BSQ. Además, los resultados mostraron relación estadísticamente significativa del régimen de entrenamiento $\left(F_{(1,179)}=4,01 ; p=0,047\right)$ y del nivel competitivo $\left(F_{(2,178)}=3,59 ; p=0,031\right)$ con los puntajes de la subescala de insatisfacción del DMS. Conclusión: Las variables deportivas (régimen de entrenamiento y nivel competitivo) estuvieron relacionadas con la insatisfacción direccionada a la delgadezy la insatisfacción con la muscularidad, aunque hayan demostrado diferentes magnitudes.

\section{Nivel de evidencia IIl; estudio el control de caso.}

Descriptores: Deportes; Cuerpo insatisfactorio; Atletas.

\section{INTRODUCTION}

Body dissatisfaction refers to concerns about one's weight, body image, and physical appearance. ${ }^{1}$ More specifically, dissatisfaction associated with a drive for thinness refers to dissatisfaction with body weight. ${ }^{2}$ Evidence shows a prevalence of body dissatisfaction associated with a drive for thinness in 20-50\% of female athletes. ${ }^{3-5}$ Coelho et al. ${ }^{6}$ indicated that body fat is the most depreciated morphological aspect in the competitive sports culture.

Above all, athletes may also have concerns about muscle size and volume ${ }^{7}$, termed muscularity dissatisfaction. ${ }^{8}$ Being a recently coined concept, evidence regarding the prevalence of muscularity dissatisfaction in female athletes is lacking. Researchers state that athletes often associate an optimization of sports performance with increased muscle mass $^{9}$ or attenuation of body weight. ${ }^{10}$

Sports are full of demands. One such demand is that athletes have training routines. Thus, athletes have a training regimen (training frequency $x$ duration) that is determined by their coaches. ${ }^{11}$ Some authors indicate that the training regimen can be closely related to body image constructs, ${ }^{9,12}$ although there is no clear scientific evidence to support this.

The goal of the training regimen is to maximize competitive performance. Athletes routinely participate in competitive events. However, the demand level varies depending on competition importance. In this context, the best athletes usually compete at national or international events. Bratland-Sanda and Sundgot-Borgen ${ }^{13}$ stated that the level at which athletes compete can be related to body dissatisfaction (thinness or muscularity). According to these authors, high-level athletes are under more pressure from their coaches to achieve good sports results. Some findings corroborate this statement ${ }^{14,15}$; however, other studies have shown contradictory results. ${ }^{16,17}$ Therefore, more studies are required to better clarify this association. Nonetheless, the previously mentioned studies only evaluated dissatisfaction associated with the drive for thinness.

Of note, an extensive search for scientific articles in the main databases (Medline, SciELO, and Scopus) identified no study in which related sports variables (training regimen and competitive level) were correlated with muscularity dissatisfaction, demonstrating that future studies in this discipline are required.

Studies aimed at analyzing the association between sports variables and body image are important since they show whether the competitive sports environment impacts the athlete's feelings regarding their body. Therefore, the findings of these studies can be insightful for future interventions in this audience and provide a framework to identify athletes who are susceptible to body dissatisfaction. In this context, the objective of this study was to analyze the association between sports variables (training regimen and competitive level) and body dissatisfaction related to the drive for thinness and muscularity dissatisfaction in female athletes.

\section{MATERIAL AND METHODS}

This cross-sectional study included only female athletes. The sample was selected by convenience sampling and consisted of 201 volunteers aged 12-36 years who are part of the sports clubs of the cities of Fortaleza/CE, Belo Horizonte/MG, Juiz de Fora/MG, Uberlândia/MG, Curitiba/PR, João Pessoa/PB, Caruaru/PE, Recife/PE, Vitória de Santo Antão/PE, Rio de Janeiro/RJ, Porto Alegre/RS, Florianópolis/SC, São Paulo/SP, and São Caetano/SP. The athletes trained a mean 3 hours a day, five times a week. The inclusion criteria required that athletes should: a) be an athlete of their respective sport for at least 2 years; b) systematically train for at least 10 hours per week; c) participate in competitions in 2014 organized by the federation of the respective sport; and d) be available to answer questionnaires and participate in anthropometric measurements.

A total of 21 athletes were excluded for not submitting fully answered questionnaires or not participating in anthropometric measurements. Therefore, the study included a final sample of 180 athletes (athletics, $n=8$; boxing, $n=4$; cycling, $n=7$; jiu-jitsu, $n=11$; judo, $n=4$; synchronized swimming, $n=31$; swimming, $n=34$; figure skating, $n=5$; water polo, $n=15$; rowing, $n=6$; diving, $n=4$; surf, $n=3$; taekwondo, $n=6$; tennis, $n=3$; triathlon, $n=4$; sailing, $n=2$; and volleyball, $n=31$ ) of various ethnicities (55\% white, 20\% black, 16\% brown, and 9\% yellow) and competitive levels (25\% international, 52\% national, 13\% state, and 10\% regional).

The participants signed an informed consent form (ICF) after receiving information about the procedures to which they would be subjected. The procedures adopted in this study met the norms of Resolution 466/12 of the National Health Council for research on human subjects.

This study was submitted to the Human Research Ethics Committee of the Faculty of Philosophy, Languages and Literature, and Human Sciences of the University of São Paulo and was approved with opinion number 119/2012 (CAE 05166712.8.0000.5407).

\section{Instruments}

The Body Shape Questionnaire (BSQ) was applied to assess dissatisfaction related to the drive for thinness. ${ }^{18}$ This 34 -question self-assessment test aims to assess the subject's concerns about their weight and physical appearance. The version used for subjects aged $\leq 18$ years was validated for Brazilian adolescents, ${ }^{19}$ and the internal consistency analysis showed an a of 0.96 and a test-retest correlation coefficient of 0.89 for women. For the sample of the present study, a Cronbach's a value of 0.96 was obtained. The version of the BSQ used for athletes aged > 18 years was validated for the young Brazilian population. ${ }^{20}$ The BSQ score is obtained by the summation of its items; higher scores indicate greater body dissatisfaction. Based on the BSQ, it is also possible to classify athletes according to degree of body dissatisfaction: no dissatisfaction (BSQ $<80$ for adolescents, BSQ $<110$ for adults), mild dissatisfaction (80 $\leq \mathrm{BSQ}<110$ for adolescents, $110 \leq \mathrm{BSQ}<138$ for adults), moderate 
dissatisfaction $(110 \leq \mathrm{BSQ}<140$ for adolescents, and $138 \leq \mathrm{BSQ}$ $<168$ for adults) and severe body dissatisfaction (BSQ $\geq 140$ for adolescents, BSQ $\geq 168$ for adults).

The Drive for Muscularity Scale (DMS), a body dissatisfaction subscale, was used to assess muscularity dissatisfaction. ${ }^{8}$ The DMS aims to assess the level of concern with muscularity and consists of five self-assessment items on a Likert scale ( $1=$ never to $6=$ always). Higher scores indicate greater muscularity dissatisfaction. In the present study, a Cronbach's alpha value of 0.76 was obtained, which indicates good internal consistency of the DMS dissatisfaction subscale.

Body fat percentage (\%BF) was estimated using the doubly indirect method. The tricipital and subscapular skinfolds were measured in athletes aged $<18$ years, while the tricipital, suprailiac, and abdominal skinfolds were measured in athletes aged $\geq 18$ years. These measurements were performed rotationally and collected three times; their mean values were considered. The \% BF was calculated using the protocols of Slaughter et al. ${ }^{21}$ and Jackson and Pollock, ${ }^{22}$ respectively, for adolescents and adults.

Demographic data (sport, age, competitive level [regional, state, national, or international], weekly training regimen [weekly frequency and daily hours]) were collected using a questionnaire created by the researchers.

\section{Procedures}

A priori, coaches from various teams of diverse sports were contacted to explain the study procedures and objectives. These coaches were approached at the training site or during competitive events.

After the coaches provided consent, a meeting was scheduled with each team to talk with the athletes and explain the study's ethical procedures. For participants under the age of 18 years, the ICF was provided to their legal guardians (parents or coach).

The study was divided into two stages. The first comprised the anthropometric measurements (skinfolds). The clubs that participated in the study provided adequate rooms for such evaluations. The measurements were performed individually to avoid interference from teammates. In addition, skinfold measurements were conducted by the same evaluator (LSF) to increase the reliability of the evaluation.

The second stage was performed shortly after the anthropometric measurements and consisted of use of the BSQ and DMS questionnaires and collection of demographic data. Importantly, only one researcher applied the questionnaires to ensure that there were no differences in the explanations provided and no influence of other researchers on the answers of the self-assessment questionnaires. The athletes received the same verbal guidance and the questionnaires included written guidance on appropriate procedures. Any doubts were clarified by the person who applied these instruments. There was no communication between the study subjects. The questionnaires were distributed when the athletes entered the room; their completion was voluntary. There was no time limit for completing the questionnaires. The data were collected from March to August 2014.

\section{Statistical analysis}

The Kolmogorov-Smirnov test was conducted to evaluate the distribution of the data (BSQ and DMS subscale). If there was no violation of parametric assumptions, the mean and standard deviation were used to describe: BSQ, DMS, \%BF, age, and training regimen. Two forward stepwise multiple linear regression models were conducted: 1) evaluation of the relationship of the training regimen (block 1 ) and competitive level (block 2) with the dissatisfaction related to the drive for thinness (BSQ); 2) evaluation of the relationship of the training regimen (block 1) and competitive level (block 2) with muscularity dissatisfaction (MSD). The $\% \mathrm{BF}$ was controlled in all statistical tests. All data were processed using SPSS 21.0 with a significance level of 5\%.

\section{RESULTS}

The descriptive data (BSQ, MSD,\%BF, training regimen, and age) of the study sample are shown in Table 1. Regarding competitive level, $17.2 \%$ of the athletes participated in regional competitions, $22.1 \%$ in state competitions, $28.7 \%$ in national competitions, and $32 \%$ in international events. According to BSQ scores, $40.2 \%$ of the athletes showed some level of body dissatisfaction (21.2\% mild, $14.8 \%$ moderate, and $4.1 \%$ severe).

The multiple linear regression model that used the training regimen and competitive level as explanatory independent variables of BSQ variance is shown in Table 2 . The findings indicate a statistically significant relationship of training regimen $\left(F_{(1,179)}=4.01 ; p=0.047\right)$ and competitive level $\left(F_{(2,178)}=3.59 ; p=0.031\right)$ with BSQ score. Moreover, \%BF was related to BSQ score $\left(F_{(1,179)}=18.66 ; p=0.01\right)$.

The multiple linear regression model that used training regimen and competitive level as explanatory variables for DMS variance is shown in Table 3. The findings show a statistically significant relationship of training regimen $\left(F_{(1,179)}=4.01 ; p=0.047\right)$ and competitive level $\left(F_{(2,178)}=3.59\right.$; $p=0.031)$ with DMS score. However, \%BF was not related to DMS score $\left(F_{(1,179)}=1.30 ; p=0.67\right)$.

Table 1. Descriptive values (minimum, maximum, mean, and standard deviation) of the study variables.

\begin{tabular}{c|c|c|c|c|c}
\hline Variable & Amplitude & Minimum & Maximum & Média & DP \\
\hline BSQ & $34-204$ & 34.00 & 173.00 & 77.94 & 35.10 \\
\hline DMS & $5-30$ & 5.00 & 25.00 & 14.76 & 5.85 \\
\hline$\% B F$ & - & 15.45 & 40.82 & 24.76 & 4.52 \\
\hline TR & - & 10.00 & 72.00 & 18.13 & 8.96 \\
\hline Age (years) & $12-36$ & 12.00 & 36.00 & 16.11 & 3.92 \\
\hline
\end{tabular}

SD, standard deviation; BSQ, Body Shape Questionnaire; DMS, Drive for Muscularity Scale; \%BF, Percentage of body fat; TR, training regimen.

Table 2. Multiple linear regression using training regimen and competitive level as explanatory variables on Body Shape Questionnaire variance in female athletes.

\begin{tabular}{c|c|c|c|c|c|c}
\hline Variable & Block & $\mathbf{B}$ & $\mathbf{R}$ & $\mathbf{R}^{\mathbf{2}}$ & $\mathbf{R}^{\mathbf{2 *}}$ & P value \\
\hline $\mathrm{TR}$ & 1 & 0.18 & 0.18 & 0.03 & 0.03 & 0.047 \\
\hline $\mathrm{CL}$ & 2 & 0.20 & 0.24 & 0.06 & 0.05 & 0.031 \\
\hline
\end{tabular}

$T R$, training regimen; $C L$, competitive level; $R^{2 *}$, adjusted $R^{2}$.

Table 3. Multiple linear regression using the training regimen and competitive level as explanatory variables on Drive for Muscularity Scale variance in female athletes.

\begin{tabular}{c|c|c|c|c|c|c}
\hline Variável & Block & $\mathbf{B}$ & $\mathbf{R}$ & $\mathbf{R}^{\mathbf{2}}$ & $\mathbf{R}^{\mathbf{2 *}}$ & $\mathbf{P}$ value \\
\hline $\mathrm{RT}$ & 1 & 0.26 & 0.26 & 0.07 & 0.06 & 0.004 \\
\hline $\mathrm{NC}$ & 2 & 0.30 & 0.35 & 0.12 & 0.11 & 0.001 \\
\hline
\end{tabular}

$T R$, training regimen; $C L$, competitive level; $R^{2 *}$, adjusted $R^{2}$.

\section{DISCUSSION}

The objective of this study was to analyze the relationship of sports variables (training regimen and competitive level) with dissatisfaction related to a drive for thinness and muscularity dissatisfaction in female athletes. According to Petrie et al., ${ }^{23}$ some intrinsic factors in competitive sports, such as training regimen and competitive level, can promote changes in body image constructs in athletes. There are studies on the relationship of competitive level with dissatisfaction related to a drive for thinnes ${ }^{14-17}$; this was not reproduced for muscularity dissatisfaction. Regarding the training regimen, although authors suggest a possible relationship with body image, 12,13 no study 
published to date analyzed its relationship with dissatisfaction related with a drive for thinness or muscularity dissatisfaction; this is thus the novelty of the current study.

According to Fortes et al. ${ }^{9}{ }^{9}$ the search for the perfect body can lead to frequent and long training sessions. Therefore, the training regimen can be closely associated with body dissatisfaction. However, although physical training attenuates body fat (depreciated morphological aspect in Western culture), the athlete can also decrease their body weight, which results in dissatisfaction related to the drive for thinness.

The training regimen accounted for $3 \%$ of the variance of the dissatisfaction related to the drive for thinness (Table 2). Longer training sessions are apparently associated with greater concerns regarding body weight. However, this can have an inverse relationship. Varnes et al. ${ }^{5}$ pointed out that, although the training regimen can lead to changes in body dissatisfaction, concerns with body weight in athletes can be associated with the natural choice of the sport. In this context, young women highly dissatisfied with their body weight may seek sports with demanding training regimens, such as artistic gymnastics and synchronized swimming, which coincidentally are sports with the highest level of dissatisfaction related to the drive for thinness according to some findings. ${ }^{4,11,24}$ Therefore, athletes with a high level of dissatisfaction related to the drive for thinness may choose to participate in sports that require intense training regimens.

Competitive level was also related to dissatisfaction associated with a drive for thinness in female athletes. Block 2 of the regression model indicated that $3 \%$ of the variance of BSQ scores was explained by competitive level (Table 2). Therefore, a higher competitive level is associated with greater dissatisfaction related to the drive for thinness. These findings are corroborated by those of other studies. ${ }^{15,25}$ Coelho et al. ${ }^{6}$ stated that national and international athletes are more predisposed to body dissatisfaction due to excessive demands and criticism from their coaches to optimize their performance. Moreover, athletes associate maximal sports performance with the attenuation of body weight. Therefore, when athletes do not meet their coaches' expectations, they may become increasingly concerned about their body weight, which explains the relationship of the competitive level with dissatisfaction related to the drive for thinness.

The results of this study showed that the training regimen explained 7\% of the variance in muscularity dissatisfaction (Table 3). Therefore, athletes with high muscularity concerns pursue sports that require intense training regimens or the training regimen increases the level of concern with muscularity. Considering the first hypothesis, young women who want to increase muscle mass may prefer sports with intense training regimens. According to El Ghoch et al.,12 a sport may be selected based on training session type, which explains the findings of the first block of the regression model (Table 3). However, considering the second hypothesis, more difficult training regimens lead to greater muscularity concerns. Bratland-Sanda and Sundgot-Borgen ${ }^{13}$ stated that increasing the training frequency and duration can lead to increased muscularity dissatisfaction.
The second regression model showed that $5 \%$ of the variance of DMS scores was explained by competitive level (Table 3). This indicates that the competitive level is related to muscularity dissatisfaction. According to Fortes et al. ${ }^{9}$ the pressure imposed by coaches, sponsors, and teammates on competitive events can lead to higher levels of concern with muscularity in athletes. Therefore, athletes competing at national and international events may be more concerned with their muscularity than those at lower competitive levels. On the other hand, this can be an inverse relationship; that is, athletes competing at regional and state events may believe that muscle mass increases are associated with improved performance. Therefore, low-level athletes may have greater muscularity concerns than high-level athletes.

Although this study shows novel results, it has some limitations, such as using questionnaires as the main research instrument. Researchers have stated that individuals may not reliably respond to self-assessment questionnaires. ${ }^{3,5,26}$ Therefore, the results may not reflect the context evaluated since the final result is derived from subjective responses. However, researchers consider these research instruments relevant if their psychometric properties are ensured. ${ }^{8,14,27}$ Another limitation is related to its cross-sectional design. Consequently, it was not possible to determine causation. This means that it is not possible to evaluate the intensity and direction of the associations found between the study's outcome and independent variables. The heterogeneity of the sample may have also influenced our findings. Despite these limitations, this study shows important findings that deserve to be discussed in the scientific literature.

\section{CONCLUSIONS}

These findings support the conclusion that sports variables (training regimen and competitive level) are related to dissatisfaction associated with drive for thinness and muscularity dissatisfaction in female athletes, although with different magnitudes.

From a practical point of view, coaches should be aware of whether their athletes are intensifying the training regimen without their consent to reduce body weight or increase muscle mass. The vulnerability to adopting more difficult training regimens can be analyzed by evaluating body dissatisfaction levels (thinness or muscularity). It is also recommended that coaches, sponsors, and teammates reduce the demands to maximize performance at competitive events, as athletes often associate improved performance with reduced body weight or increased muscle mass.

And finally, longitudinal studies should be conducted to investigate the influence of sports variables on the body image constructs of athletes. Studies that include male athletes in the analyses are also suggested.

All authors declare no potential conflict of interest related to this article.

AUTHORS' CONTRIBUTIONS: Each author made significant individual contributions to this manuscript. LSF (0000-0002-0778-769X)*: data collection, writing, data analysis; SSA (0000-0002-1551-9062)*: data analysis, revision of the article; MECF (0000-0002-3294-7560)*: creation of the research project, supervision. All authors approved the final version of the manuscript. *ORCID (Open Researcher and Contributor ID).

\section{REFERENCES}

1. Laus MF, Kakeshita IS, Costa TM, Ferreira ME, Fortes Lde S, Almeida SS. Body image in Brazil: recent advances in the state of knowledge and methodological issues. Rev Saude Publica. 2014;48(2):331-46.

2. Rodgers R, Cabrol H, Paxton SJ. An exploration of the tripartite influence model of body dissatisfaction and disordered eating among Australian and French college women. Body Image. 2011;8(3):208-15.

3. SwamiV, Steadman L, Toveé MJ. A comparison of body size ideals, body dissatisfaction, and media influence between female track athletes, martial artists, and non-athletes. Psychol Sport Exerc. 2009;10(6):609-14.
4. Fortes LS, Neves CM, Filgueiras JF, Almeida SS, Ferreira ME. Body dissatisfaction, psychological commit ment to exercise and eating behavior in young athletes from aesthetic sports. Rev Bras Cineantropom Desempenho Hum. 2013;15(6):695-704.

5. Varnes JR, Stellefson ML, Janelle CM, Dorman SM, Dodd V, Miller MD. A systematic review of studies comparing body image concerns among female college athletes and non-athletes, 1997-2012. Body Image. 2013;10(4):421-32. 
6. Coelho GM, Soares Ede A, Ribeiro BG. Are female athletes at increased risk for disordered eating and its complications? Appetite. 2010;55(3):379-87

7. Raudenbush B, Meyer B. Muscular dissatisfaction and suplplement use among male intercollegiate athletes. J Sports Exerc Psychol. 2003;25(2):161-70.

8. Campana AN, Tavares MC, Swami V, da Silva D. An examination of the psychometric properties of Brazilian Portuguese translations of the Drive for Muscularity Scale, the Swansea Muscularity Attitudes Questionnaire, and the Masculine Body Ideal Distress Scale. Psychol Men Masculinity. 2013;14(4):376-88.

9. Fortes LS, Almeida SS, Ferreira ME. Imagem corporal e transtornos alimentares em atletas adolescentes: uma revisão. Psicol Estudo. 2013;18(4):667-77.

10. Haase AM. Weight perception in female athletes: associations with disordered eating correlates and behavior. Eat Beha. 2011;12(1):64-7.

11. Krentz EM, Warschburger P. A longitudinal study investigation of sports-related risk factors for disordered eating in aesthetic sports. Scan J Med Sci Sports. 2013;23(3):303-10.

12. El Ghoch M, Soave F, Cafugi S, Dalle Grave R. Eating disorders, physical fitness and sport performance: A systematic review. Nutrients. 2013;5(5):5140-60.

13. Bratland-Sanda S, Sundgot-Borgen J. Eating disorders in athletes: overview of prevalence risk factors and recommendations for prevention and treatment. Eur J Sport Sci. 2013;13(5):499-508

14. Gomes AR, Martins C, Silva L. Eating Disordered Behaviors in Portuguese athletes: the influence of personal, sport, and psychological variables. Eur Eat Disord Rev. 2011;19(3):190-200.

15. Holm-Denoma JM, Scaringi V, Gordon KH, Van Orden KA, Joiner JrTE. Eating Disorder Symptoms among Undergraduate Varsity Athletes. Club Athletes, Independent Exercisers. And Nonoexercises. Int J Eat Disorders. 2009;42(1):47-53.

16. Fortes LS, Paes ST, Amaral AC, Ferreira ME. Insatisfação corporal e comportamento alimentar inadequado em jovens nadadores segundo níveis econômicos e competitivos. J Bras Psiquiatr. 2012;61(1):20-4.

17. Fortes LS, Ferreira MEC. Comparison of body dissatisfaction and inappropriate eating behavior in adolescent athletes of different sports. Rev Bras Educ Fís Esporte. 2011;25(4):707-16

18. Cooper PJ, Taylor MJ, Cooper Z, Fairburn CG. The development and validation of Body Shape Questionnaire Int J Eat Disorders. 1987;6(4):485-94.

19. Conti MA, Cordás TA, Latorre MR. A study of the validity and reliability of the Brazilian of the Body Shape Questionnaire (BSQ) among adolescents. Rev Bras Saude Mater Infant. 2009;9(3):331-8.

20. Di Pietro M, Silveira DX. Internal validity, dimensionality and performance of the Body Shape Questionnaire in a group of Brazilian college students. Rev Bras Psiquiatr. 2009;31(1):21-4.

21. Slaughter MH, Lohman TG, Boileau RA, Hoswill CA, Stillman RJ, van Loan MD, et al. Skinfold equations for estimation of body fatness in children and youth. Human Biology. 1988;60(5):709-23.

22. Jackson AS, Pollock ML Generalized equations for predicting body density of men. Br J Nutrition. 1978:40(3):497-504

23. Petrie T, Galli N, Greenleaf C, Reel J, Carter J. Psychological correlates of bulimic-symptomatology among male athletes. Psychol Sport Exerc. 2014;15(6):680-7.

24. Peden J, Stiles BL, Vandehey M, Diekhoff, G. The effects of external pressures and competitiveness on characteristics of eating disorders and body dissatisfaction. J Sport Social Issues. 2008;32(4):415-29.

25. Neves CM, Filqueiras JF, Fortes LS, Ferreira ME. Comportamentos alimentares em ginastas de elite: associação com o perfeccionismo e o estado de humor. Rev Educ Fís/UEM. 2013;24(3):359-69.

26. Gay IL, Monsma EV Torres-McGehee TM. Developmental and contextual risks of social physique anxiety among female athletes. Res Q Exercise Sport. 2011; 82(2):168-177.

27. Fortes LS, Almeida SS, Ferreira ME. Anthropometric indicators of body dissatisfaction and inappropriate eating behaviors in young athletes. Rev Bras Med Esporte. 2013;19(1):35-9. 